\title{
THE IMPORTANCE OF NITROGEN IN THE HEAT TREATING OF FERROUS AND NON-FERROUS METALS AND ALLOYS
}

\author{
Marius VASILESCU, Mircea DOBRESCU \\ Politehnica University of Bucharest, Romania \\ e-mail: vmarius_sim_pub@yahoo.com, dobrescu.mircea@gmail.com
}

\begin{abstract}
Nitrogen was first used as the base gas for treating and annealing semifinished products of steel. Since then the use of industrial gases has spread to cover the full range of heat treatment processes for ferrous and non-ferrous metals and alloys. This paper is focused on titanium and titanium alloys nitriding but also on the recommended nitrogen process atmosphere for ferrous and non-ferrous metals and alloys.
\end{abstract}

KEYWORDS: nitrogen, heat treating, steels, titanium

\section{Introduction}

Many processes can only be performed using a mixture of industrial gases. Table 1 shows a list of some of the most important processes and atmospheres.
It is evident that a wide range of gases is employed, even for the more common treatments. For more specialist applications even more gases can be useful, including oxygen, helium, sulphur hexafluoride and carbon monoxide [1].

Table 1. Recommended process atmospheres

\begin{tabular}{|c|c|c|}
\hline Process & Atmosphere & Comments \\
\hline \multirow{2}{*}{ Low alloy steel annealing } & Nitrogen/ hydrogen & Often non-flammable mixtures \\
\cline { 2 - 3 } Low alloy steel hardening & Hydrogen & For faster processing in bell furnaces \\
\cline { 2 - 3 } & Nitrogen/ natural gas & Often non-flammable mixtures \\
\hline Stainless steel annealing & Nitrogen/ methanol & Zone \\
\hline Copper annealing & Nitrogen/ hydrogen & $\begin{array}{c}\text { Zoned for 100\% hydrogen in the hot } \\
\text { zon fort exposure } \\
\text { times }\end{array}$ \\
\hline Aluminium annealing & Nitrogen/ hydrogen & Low purity \\
\hline Titanium annealing & Nitrogen & Zoned \\
\hline Sintering iron-based & Argon & - \\
\hline Carburising & Nitrogen/ methanol/ natural gas & Plus ammonia for carbonitriding \\
\hline Ferritic nitrocarburising & Nitrogen/ ammonia/ carbon dioxide & Nitrogen for purge \\
\hline Nitriding & Ammonia/ nitrogen & \\
\hline
\end{tabular}

The primary function of the furnace is the treatment of any product to protect it from atmospheric oxidation. A bright product is usually required, but for some processes only protection from gross oxidation is needed. An example of the former is the annealing of copper water pipes or stainlesssteel sink tops and an example of the latter is billet reheating prior to forging. The presence of only a few parts per million of oxygen will oxidise almost any metal at its annealing temperature. Even the highest purity commercially available nitrogen contains one or two parts per billion of oxygen and furnace leaks are inevitable. Therefore, to produce a bright product, this oxygen must be reacted with an active gas such as hydrogen producing $\mathrm{H}_{2} \mathrm{O}$, Eq. 1 .

$$
1 / 2 \mathrm{O}_{2}+\mathrm{H}_{2} \rightarrow \mathrm{H}_{2} \mathrm{O}
$$


Therefore, the concept of protective atmospheres is to use an inert gas with sufficient hydrogen or other reducing species to prevent adventitious oxygen, originating from air leaks, from oxidizing the work and tarnishing it.

The furnace atmosphere can also be used to modify the surface chemistry of the material. Common thermochemical treatments for steel are all based on the diffusion of carbon and/ or nitrogen into the surface layers of finished or almost finished components to produce the desired properties.

Examples of such processes are carburizing, typically applied to gears to produce a wear-resistant surface layer on a tough core and ferritic nitrocarburising, typically applied to components requiring a combination of wear and corrosion resistance on a cheap, mild steel substrate.

\section{Supply technologies}

Large users of nitrogen-based atmospheres have generated the required nitrogen onsite by cryogenic distillation, often as a co-product with oxygen. Such plants produce high purity nitrogen at low cost owned and operated by an industrial gas company and the gas is supplied on a contract basis. Typical users of these supply schemes would be steelworks and large aluminium plants.

New developments in cryogenic plant design over the last few years have led to the introduction of small generators, which are installed on a gas user's premises to produce relatively small volumes of nitrogen at high purity. One of the key features of these plants is the use of small amounts of liquid nitrogen to make up the heat balance in their low temperature distillation columns in the place of the expansion turbines used in larger plants. For this reason, these plants are often called „liquid assist” plants.

Non-cryogenic nitrogen generally costs substantially less to produce than nitrogen from liquid assist plants. The residual oxygen means that noncryogenically generated nitrogen is not universally applicable. A list of some of those applications for which it is most suitable is shown in Table 2.

Table 2. Applications for non-cryogenically generated nitrogen

\begin{tabular}{|c|c|c|}
\hline Process & Atmosphere & Comments \\
\hline Steel annealing & Nitrogen/ hydrogen & $\begin{array}{c}\text { Limited application. } \\
\text { Pre-reaction usually required. }\end{array}$ \\
\hline Copper annealing & Nitrogen/ hydrogen & Pre-reaction usually required. \\
\hline Aluminium annealing & Nitrogen & Applicable to all grades \\
\hline Carburising & $\begin{array}{c}\text { Nitrogen/ methanol/ } \\
\text { hydrocarbon }\end{array}$ & - \\
\hline Austenitic nitrocarburising & Nitrogen/ methanol/ ammonia & - \\
\hline Ferritic nitrocarburising & $\begin{array}{c}\text { Nitrogen/ ammonia/ carbon } \\
\text { dioxide }\end{array}$ & $\begin{array}{c}\text { Reduced carbon dioxide } \\
\text { requirement }\end{array}$ \\
\hline Nitriding & Nitrogen/ ammonia & Purging only \\
\hline Decarburising & Nitrogen/ hydrogen & Pre-reaction usually required. \\
\hline Copper brazing & Nitrogen/ hydrogen & - \\
\hline
\end{tabular}

\section{Nitriding of steels and stainless steels with controlled layer}

It is classically assumed that only plasma nitriding is able to control all processed parameters in order to regulate the type and nature of the nitriding layer which is built. Recent scientific research has proven, on the other hand, that similar and reproductible results can be obtained with gas nitriding. It is then possible to control the type (alphanitride, lambda-nitride or epsilon-nitride) as well as their respective growth kinetics.

\section{Titanium strengthening by impurities action}

Among the interstitial elements in titanium such as $\mathrm{C}, \mathrm{N}, \mathrm{O}$, the strongest effect is produced by nitrogen, followed by oxygen and carbon, Eq. 2 .

$$
\mathrm{HB}=196 \% \mathrm{~N}+158 \% \mathrm{O}+45 \% \mathrm{C}+20 \% \mathrm{Fe}+57
$$

where:

$\mathrm{HB}$ - Brinell hardness of titanium alloy;

57 - Pure titanium hardness.

The influence of oxygen and nitrogen on the hardness of titanium is shown in Fig. 1.
When adding simultaneously oxygen and nitrogen or after plasma nitriding in a very low oxygen atmosphere, tensile characteristics are enhanced. 


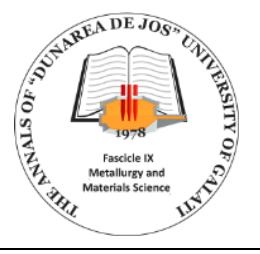

THE ANNALS OF “DUNAREA DE JOS” UNIVERSITY OF GALATI

FASCICLE IX. METALLURGY AND MATERIALS SCIENCE

No. 1 - 2019, ISSN 2668-4748; e-ISSN 2668-4756

Article DOI: $\underline{\text { https://doi.org/10.35219/mms.2019.1.05 }}$

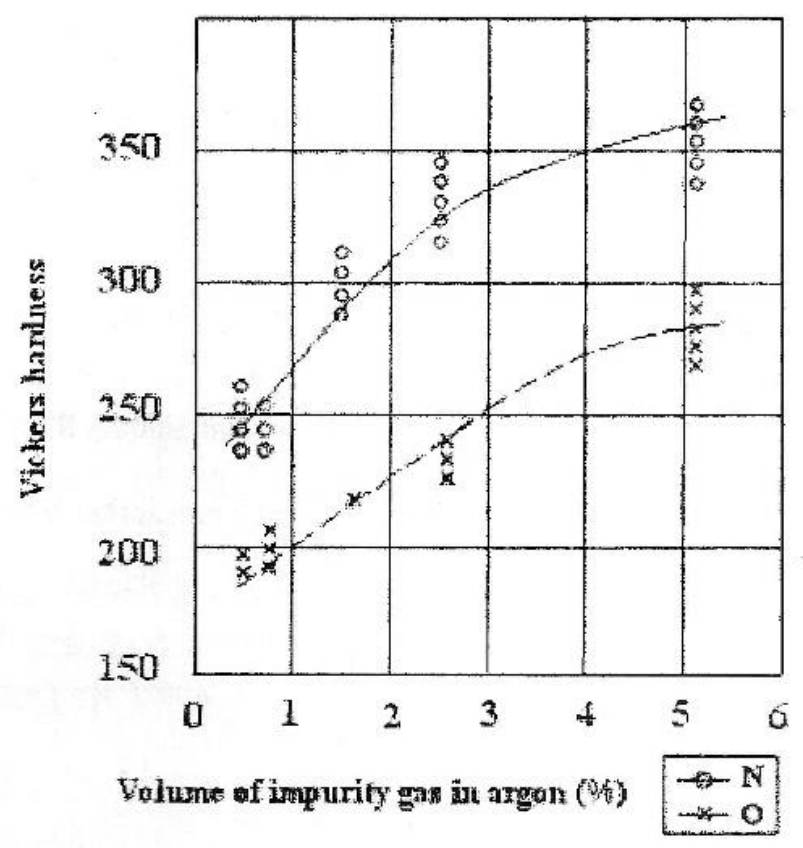

Fig. 1. Vickers hardness of titanium vs. oxygen and nitrogen content

\section{Plasma nitriding of titanium}

For plasma nitriding of titanium, microhardness is increased with temperature and duration of the treatment. The best results $(1120 \mu \mathrm{HV})$ were obtained in the conditions $850{ }^{\circ} \mathrm{C} / 5 \mathrm{~h}$ (Fig. 2) [2].

In Figure 2 is shown the hardness of titanium probe with the distance from probe surface.

By X-Ray Diffraction (Figure 3 we identified two hard compounds $\mathrm{TiN}(\delta) \mathrm{CFC}$ and $\mathrm{Ti}_{2} \mathrm{~N}(\varepsilon)_{\text {tetragonal }}$.

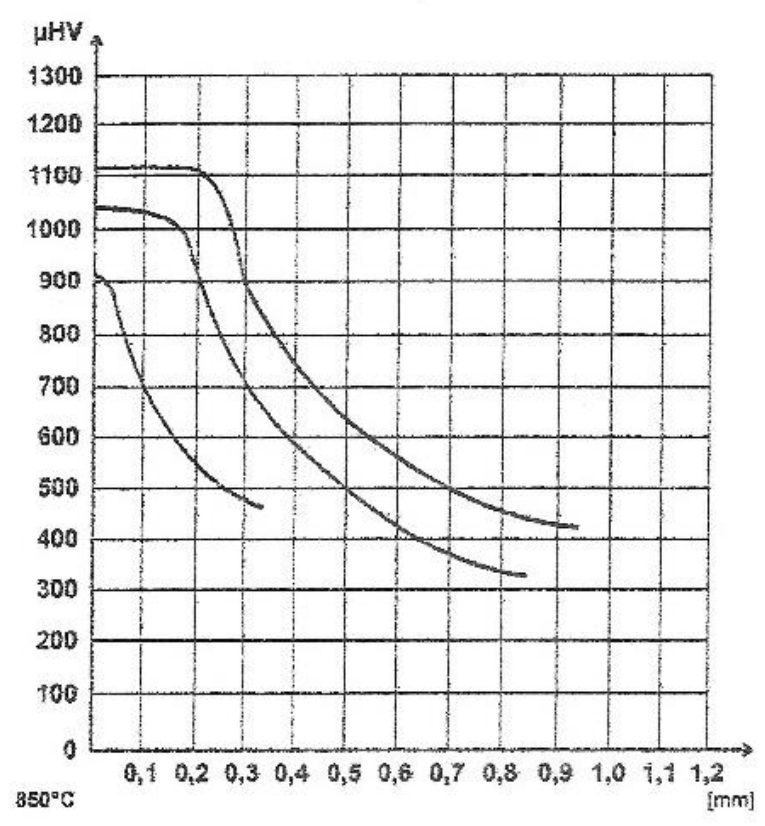

Fig. 2. Hardness of Ti after nitriding $\left(850^{\circ} \mathrm{C}\right) \mathrm{vs}$. the distance from probe surface 


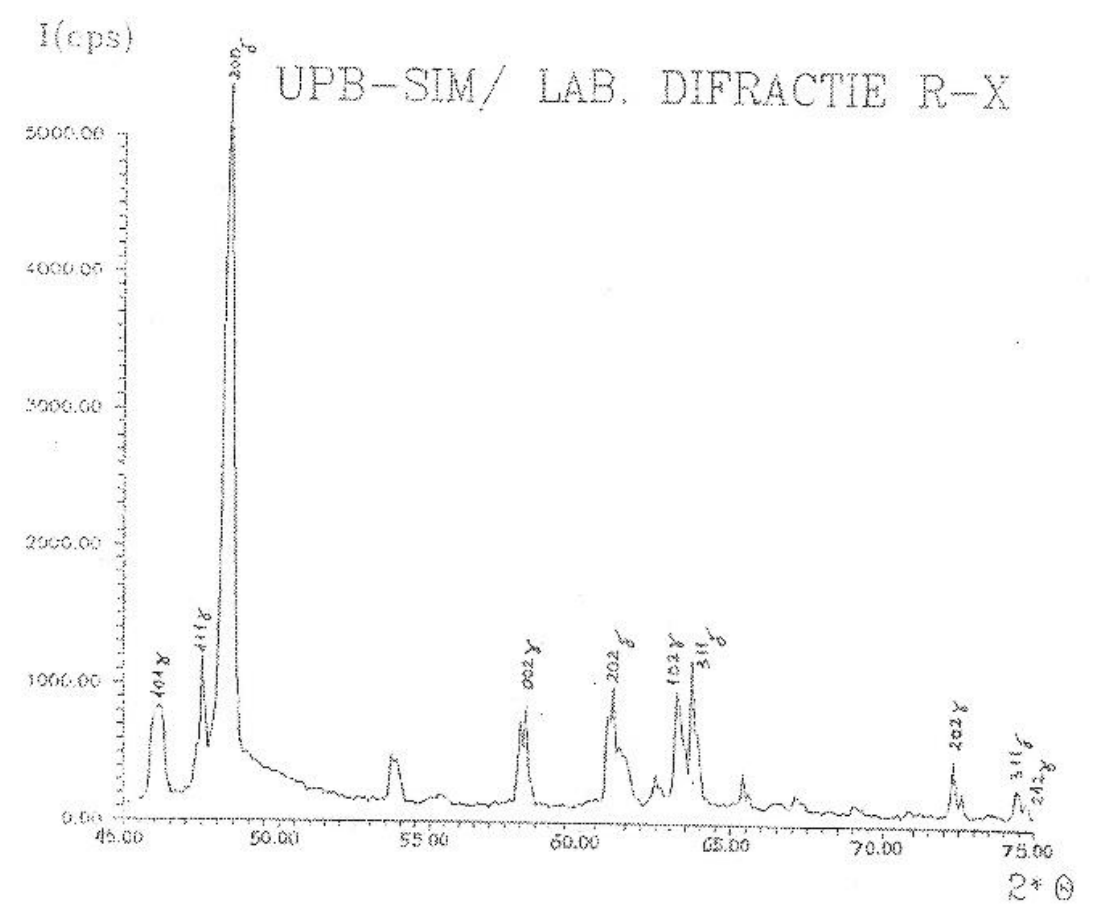

Fig. 3. X-Ray Diffraction Pattern after Titanium Nitriding $\left(850^{\circ} \mathrm{C}\right)$

\section{Oxy-nitriding of titanium}

Because of the difficult control of nitriding process, some probes underwent oxidation. In spite of these facts, oxy-nitriding produces a higher microhardness $(1300 \mu \mathrm{HV})$ in the condition 850 ${ }^{\circ} \mathrm{C} / 2 \div 3 \mathrm{~h}$. The duration of oxy-nitriding didn't influence hardness significantly [3].

By X-Ray Diffraction we identified an oxynitride TiNO with CFC cell.
To increase the strength properties of titanium, oxygen content varies in the range $0.1-0.2 \%$ [4].

A slow solution treatment temperature followed (after quenching) by an aging at low temperature (540 ${ }^{\circ} \mathrm{C}$ ) produced a fine $\alpha-$ grain with the best tensile properties [5].

A simultaneous presence of small quantities of nitrogen $(0.08 \%)$ and oxygen $(\leq 0.34 \%)$ increase tensile strength of Ti-6Al-3.5Mo-1.7Zr-0.2Si alloy as is shown in Table 3.

Table 3. The influence of oxygen and nitrogen on tensile strength of some titanium alloys

\begin{tabular}{|c|c|c|c|c|c|}
\hline \multirow{2}{*}{ Alloy } & \multirow{2}{*}{$\begin{array}{c}\text { Sample } \\
\text { No. }\end{array}$} & \multirow{2}{*}{$\begin{array}{c}\mathrm{N} \\
\text { (wt.\%) }\end{array}$} & \multirow{2}{*}{$\begin{array}{c}\text { O } \\
\text { (wt.\%) }\end{array}$} & $\begin{array}{c}\text { Initial } \\
\text { (heat treated) }\end{array}$ & $\begin{array}{c}\text { After plasma } \\
\text { nitriding }\end{array}$ \\
\hline \multirow{4}{*}{ Ti-1.3Mo-1.5Ni-0.7W } & 1 & 0.07 & 0.27 & 923 & 1000 \\
\cline { 2 - 6 } & 2 & 0.04 & 0.19 & 935 & 1100 \\
\cline { 2 - 6 } & 3 & 0.03 & 0.15 & 920 & 1050 \\
\cline { 2 - 6 } & 4 & 0.01 & 0.12 & 910 & 950 \\
\cline { 2 - 6 } & 5 & 0.05 & 0.23 & 930 & 1150 \\
\hline \multirow{3}{*}{ Ti-5Al-2.5Fe } & 6 & 0.04 & 0.18 & 925 & 1100 \\
\cline { 2 - 6 } & 7 & 0.06 & 0.22 & 980 & 1059 \\
\cline { 2 - 6 } & 8 & 0.09 & 0.32 & 970 & 1020 \\
\hline \multirow{3}{*}{ Ti-6Al-3.5Mo-1.7Zr-0.2Si } & 9 & 0.07 & 0.32 & 1120 & 1300 \\
\cline { 2 - 6 } & 10 & 0.03 & 0.30 & 1120 & 1280 \\
\cline { 2 - 6 } & 11 & 0.08 & 0.35 & 1150 & 1290 \\
\cline { 2 - 6 } & 12 & 0.05 & 0.30 & 1100 & \\
\hline
\end{tabular}




\section{Nitrogen for ni-ti coupling fabrication}

The main application of TiNi shape memory alloys is couplings that join $\mathrm{Ti}-3 \mathrm{Al}-2.5 \mathrm{~V}$ hydraulic tubing in jet aircraft [6]; the principle is illustrated in Fig. 4.
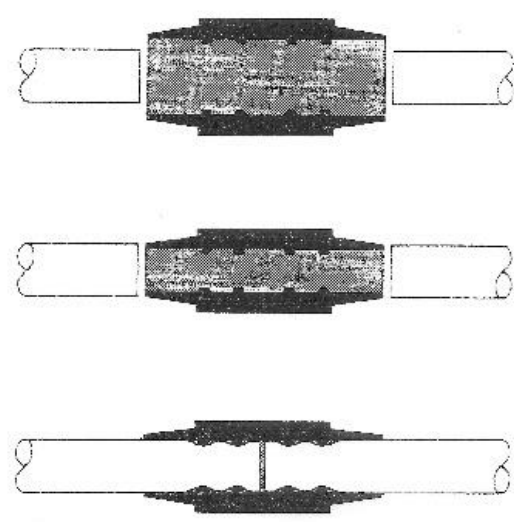

Fig. 4. The NiTi shape-memory alloy coupling, with sealing bands on the inner surface, is machined in the austenitic condition with an inner diameter (ID) smaller than the outer diameter $(O D)$ of the tubes to be joined. The coupling is cooled below MF in liquid nitrogen, and mechanically expanded while martensitic to an ID then, slightly cooled to ambient temperature. The coupling shrinks to fit tightly, locking the coupling and tubing tightly together to form a metal-to-metal seal

The coupling, with sealing bands on the inner surface, is machined in the austenitic condition with an inner diameter (ID) smaller than the outer mechanically expanded while martensitic, to an ID slightly larger than the OD tube $[7,8]$. The expanded coupling is stored in liquid nitrogen until ready to install, $[9,10]$. Then it is slipped over the tubing ends, using simple tools designed to position the coupling properly. During subsequent warming to ambient temperature, the coupling shrinks to fit tightly. The tubing constrains the coupling from shrinking to its original size, locking the coupling and tubing tightly together to form a metal-to-metal seal [11].

\section{Conclusions}

Regarding the gas atmosphere processes, in the paper is shown the influence of nitrogen on heat treatment of titanium and other materials like aluminium, copper and steel.

Nitrogen is important in $\mathrm{Ti}$ and $\mathrm{Ti}$ alloys strengthening also as impurity.

For increasing titanium hardness plasma nitriding and oxy nitriding technologies are suitable.

Nitrogen is used also for $\mathrm{Ni}-\mathrm{Ti}$ shape memory couplings fabrication.

\section{References}

[1]. ***, Materials world, no. 2, p. 25-33, 2001.

[2]. ***, Metalurgia, no. 11, p. 21-22, 2001.

[3]. Dobrescu M., Dumitrescu C., Vasilescu M., Titanul şi aliajele sale, Ed. Printech, 2000.

[4]. Okazaki Y., J. Japan Inst. Metals, no 59, vol. 1, p. 1098-1105, 1995.

[5]. Hocheid R., Klima R., Beauvais C., Memoires scientifique, Rev. Metallurg., no. 9, p. 585-590, 1980.

[6]. Yoder G. R., Flores F. H., Eylon D., Metallurgical Transaction, vol. 15A, no. 1, p. 183-187, 1985.

[7]. House J. E., House K. A., Descriptive Inorganic Chemistry, ( $3^{\text {rd }}$ Edition), p. 197-214, 2016.

[8]. House J. E., House K. A., Descriptive Inorganic Chemistry, ( $2^{\text {nd }}$ Edition), p. 277-299, 2016.

[9]. Occelli M. L., Auroux A., Kalwei M., Wolker A., Eckert H., Studies in Surface Science and Catalysis, vol. 134, p. 41-58, 2001.

[10]. Aggarwal S., Lyn C. P., Karimi I. A., Computer Aided Chemical Engineering, vol. 31, p. 895-899, 2012.

[11]. Webb G. A., Encyclopedia of Spectroscopy and Spectrometry, (2 ${ }^{\text {nd }}$ Edition), p. 1790-1799, 1999. 